\title{
The Influence of Cognitive, Unique and Affective Attraction Images on Loyalty through Visitor Satisfaction: A Case Study of Sudimoro Coffee Center, Malang. Indonesia
}

\author{
Edi Riyanto, Bambang Supriadi*, Syarif Hidayatullah \\ University of Merdeka Malang \\ Indonesia
}

\begin{abstract}
Image of cognitive, unique, and effective attractiveness is a factor that makes tourists decides to visit a tourist destination. After tourists choose to visit a tourist destination, hope is the emergence of a good impression from the tours that have been seen because tourists have been satisfied with what they get so that loyal loyalties arise to visit again at tourist destinations. The aims of this research are: 1The Effect of Cognitive Attractiveness Image on Visitor Satisfaction: 2 The Influence of Unique Attraction Image on Visitor Satisfaction; 3 Effect of Affective Attractiveness Image on Visitor Satisfaction; 4 The Effect of Cognitive Attractiveness Image on Visitor Loyalty; 5 The Effect of Unique Attractiveness Image on Visitor Loyalty; 6 Effect of Affective Attractiveness Image on Visitor Loyalty; 7 The Effect of Visitor Satisfaction on Visitor Loyalty; 8 The Effect of Cognitive Attractiveness Image on Loyalty through Visitor Satisfaction; 9 The Effect of Unique Attractiveness Image on Loyalty through Visitor Satisfaction; 10 Effect of Affective Attractiveness Image on Loyalty through visitor satisfaction.
\end{abstract}

Keywords: Attractiveness, Loyalty Visitors, Malang.

\section{INTRODUCTION}

The tourism sector in Indonesia is currently growing rapidly; the tourism sector affects the country's foreign exchange earnings. The beginning of 2020 is a period that is quite influential on income from the tourism sector. Since the spread of the Covid-19 virus in various countries, the tourism sector has been affected. Therefore, it is necessary to make a breakthrough in the tourism business in culinary tourism that can make a positive contribution to the tourism sector for an area, which has implications for all parties involved in the tourism industry to manage tourism professionally. The ability of a place to manage its tourism objects will provide great benefits for the area concerned (Putra, 2017: 202). The fierce competition of the tourism industry demands several goals: to build and maintain a favorable image, develop attractive tourism offerings, and achieve customer satisfaction and loyalty for tourism development.

Tourism exists and develops because of tourists; one of the characteristics of tourism development in a country is the number of tourists/visitors who enter the tourist attractions. In tourism, visitor loyalty is an important thing to be built by a tourist destination service business because it can provide great benefits. One of them is, there is more trust felt by visitors. The more confidence felt by visitors, can influence visitors to recommend to the closest people and others to come to visit a tourist destination so that the existence and number of visitors who come to the tourist destination can experience an increase. This statement is supported by several previous researchers, including Chi et al. (2007), Hanif et al. (2016). According to Chiu et al. (2016), Siswantini et al. (2017), and Isnaini, et al. (2018) which states that tourist loyalty is indeed important for a tourist destination because more loyal visitors can affect the development of the tourist destination itself. One of the things that affect loyalty is the satisfaction felt by tourist visitors. Satisfaction can increase the intensity of tourist visits to a tourist destination. In addition, satisfied visitors are more likely to make return visits. The emergence of a loyal attitude can also be caused by the services and facilities provided well that can exceed the expectations expected by tourists. This statement is supported by several previous researchers, namely, Lamidi et al. (2013) and Fikri et al.(2016). Therefore, tourism destination management service businesses need to increase and maintain satisfaction. 
Maintaining and maintaining a good image of the destination in visitors' eyes is also important for tourism destination service businesses to pay attention to. A tourist destination with a good and positive image can encourage visitors to be loyal in the future. Therefore, the more positive the idea of the destination, the more visitors will prefer the tourist destination to visit. However, according to Lamidi et al. (2013), ad Amalia et al. (2016), the destination's image does not directly affect visitors' loyalty to tourist destinations.

Loyalty, satisfaction, and destination image are important to be built by tourist destination service businesses to maintain and improve the existence of a tourist destination. Customer loyalty is a continuation of customer satisfaction in using the facilities and services provided by a tourist destination and remaining a customer of the tourist destination. Therefore, customer loyalty has a very important role in the tourism industry; retaining customers means increasing profits and maintaining the viability of the tourism industry.

Seeing the many destinations in Malang Raya certainly affects other tourist destination service businesses competing to create and develop existing business opportunities by making tourist destinations more attractive to visit. In addition to creating new tourist destinations, some tourist service businesses sometimes develop and innovate existing tourist destinations. Currently, several tourist destinations in Malang are growing by providing culinary tours, souvenirs, special foods, and coffee drink centers with various facilities provided by coffee shop managers that can attract visitors to come to gather. Culinary tourism destination Sudimoro Malang coffee center is a collection of coffee shops along Ikan Tombro Street / the new name of Sukarno Hatta Canal Street, Malang. More than 25 coffee shops are operating here. The Sudimoro Malang coffee center offers the experience of drinking coffee with the distinctive concept of each coffee shop. The main product offered from the Sudirmoro coffee center is the typical coffee taste from coffee-producing centers around Malang, such as Dampit coffee producers, Karangploso coffee, Ngantang coffee, and others, with added blends from each coffee shop to produce a unique coffee menu. Has a unique and distinctive coffee taste image. In addition to the taste image, the Sudimoro coffee center also offers an atmosphere of rice fields and roadside with various concepts, such as minimalist, joglo, industrial, garden, and others. In Malang, the coffee trend has become a culture in recent years. The audience mostly comes from young people, either students or office workers.

The Sudimoro coffee center, as a service provider, must always follow the development of customer expectations; this is done to fulfill what is expected by customers so that it will create customer satisfaction. Customer satisfaction cannot be separated in every service or service because customer satisfaction will make the Sudimoro coffee center more advanced and can provide satisfaction to customers.

This positive impression can form a positive destination image for the culinary tourism destination of the Sudimoro coffee center so that it can influence visitors not to doubt when choosing to visit this tourist destination.

\section{LITERATURE REVIEW}

\subsection{Image of Cognitive Attractiveness.}

The image of a cognitive tourist attraction is a person's knowledge and thoughts about an object (Agapito et al., 2013). With a cognitive approach, the image of a tourist destination is evaluated through the attributes of resources and attractions owned by a tourist place that motivates a person to visit the site (Lopes, 2011). According to researchers, cognitive attractiveness is the experience gained by tourists, tourist attractions in a destination, the environment and infrastructure, entertainment, and the cultural traditions of the goal.

\subsection{Image of Unique Attraction The}

image of a unique attraction relates to the uniqueness possessed or contained in a tourist attraction. A tourist attraction certainly has a different level of originality. It is this uniqueness that provides a magnet for tourists to visit a tourist attraction. Consists of the natural environment, the attractiveness of a destination, and local attractions that exist in these destinations (Hailin Qu et al., (2011: 470).

\subsection{Fascination AffectiveImagery.}

Imagery appeal of Affective refers to the emotions and feelings attached to the goal destination (Destari, 2017). The affective component refers to how a person feels about the object (Ahmad, 2015). 
The affective component is related to the motives of the tourist for choosing one destination at the expense of another. The affective component becomes operational in connection with the tourist"evaluation of destination choice (Jorgensen In Ghabriella Bella, 2017); the affective component is associated with a pattern of tourists choosing one goal at the expense of the other. And it became operational in connection with the evaluation of tourists to the destination choice. According to Artuğer et al. (2013), divide an effective image's dimensions into three: 1 . A lively city, 2. Exciting city. Ing city), and 3. A(pleasant city pleasant city).

\subsection{Visitor Satisfaction.}

The concept of customer satisfaction is not a simple process because consumers have a role in service encounters and influence the satisfaction set. Therefore, consumers are the main focus in discussing satisfaction in the service process. Thus, the company is committed that starting from customer satisfaction in vision and mission statements, advertisements, and meetings, which all involve consumers (Adinegara et al., 2017). His experience (Coban, 2012). Yuksel et al. (2010) measure satisfaction with three items, the first relates to whether or not tourists are happy with their decision to visit a tourism destination, second is the belief that choosing a related destination is the right thing, and third is the overall level of satisfaction during a trip to a tourism destination.

\subsection{Visitor Loyalty.}

According to Oliver (2010), loyalty is a deeply held commitment by customers to support or repurchase a preferred product or service in the future despite situational influences and marketing efforts causing customers to switch. Two factors determine loyalty to tourism destinations. First, Intention to revisit the goal, meaning that tourists show their loyalty by reviewing related tourist destinations in the future. Second, Say positive things about the destination and recommendations to others, meaning that tourists show their loyalty by saying positive things about tourist destinations and then recommending them to others. According to (Artuğer, et al. 2013).

\section{HYPOTHESIS}

H1: It is suspected that the image of cognitive attractiveness significantly affects visitors' satisfaction with culinary tourism at the Sudimoro coffee center in Malang.

H2: It is suspected that the image of a unique attraction has a significant effect on visitors' satisfaction with culinary tourism at the Sudimoro coffee center in Malang.

H3: It is suspected that the image of affective attractiveness has a significant effect on visitors' satisfaction with culinary tourism at the Sudimoro coffee center in Malang.

H4: It is suspected that the image of cognitive attractiveness significantly affects visitors' loyalty to culinary tourism at the Sudimoro coffee center in Malang.

H5: It is suspected that the unique attractiveness image significantly affects visitors' loyalty to culinary tourism at the Sudimoro coffee center in Malang.

H6: It is suspected that the image of affective attractiveness has a significant effect on visitors' loyalty to culinary tourism at the Sudimoro coffee center in Malang.

H7: It is suspected that visitor satisfaction has a significant effect on visitors' loyalty to culinary tourism at the Sudimoro coffee center in Malang.

H8: It is suspected that the image of cognitive attractiveness significantly affects visitor loyalty through visitors' satisfaction with the Sudimoro coffee center culinary tourism in Malang.

H9: It is suspected that the image of unique attractiveness has a significant effect on visitor loyalty through visitors' satisfaction to culinary tourism at the Sudimoro coffee center, Malang.

H10: It is suspected that the image of affective attractiveness has a significant effect on visitor loyalty through visitors' satisfaction with the Sudimoro coffee center culinary tourism in Malang. 


\section{METHODOLOGY}

\subsection{Research Design}

This research is quantitative to examine the effect of the independent variable on the dependent variable.

\subsection{Sample and Data Collection}

The population used in this study were visitors to culinary tourism at the Sudimoro coffee center, Malang. The people of this study were 68 people for one month (15 days) and 25 coffee shops in the Sudimoro coffee center, Malang. The number of samples in this study was 68 people, so the sampling technique was a census, where all population members were sampled.

\subsection{Analysis Techniques}

The data analysis method in this study was carried out with the following techniques:

- Descriptive

Analysis This analysis is to explain the picture in measurable conditions. After the data was collected, tabulation was carried out to analyze the description further using the mean statistical tool. The technique used to describe the field data descriptively by interpreting the results of data processing through tabulation.

- Path

Analysis The analysis used three exogenous variables, one mediating variable, and one endogenous variable. The relationship between variables and indicators is formative, so factor analysis uses the bivariate correlation technique (validity test) and formula Chronbach's Alpha (reliability test).

- Multiple Linear Regression Analysis is a regression with one dependent variable and two or more independent variables. The multiple regression equation can be formulated as follows:

Description:

$$
\begin{gathered}
\mathrm{Y}=\alpha+\beta_{1} \mathrm{YX}+\beta Y Z+\epsilon \\
\mathrm{Z}=\alpha+\beta_{1} X+\varepsilon
\end{gathered}
$$

$$
\begin{aligned}
\mathrm{Y} & =\text { Variabel Dependen } \\
\dot{\beta}_{1} & =\text { Konstanta } \\
\mathrm{X} & =\text { First Koefisien Regresi } \\
\mathrm{Z} & =\text { First Variabel Independen } \\
& \text { Variabel mediasi } \\
\bullet & =\text { Error }
\end{aligned}
$$

\section{RESEARCH RESULT}

\subsection{Overview of Research Objects}

Respondents in this study were visitors to the coffee center Sudimoro Malang. In this study, the researchers grouped the profiles of respondents based on the gender and age of the respondents. The following are the grouping results of respondents' profiles: a. gender showed that male respondents were 45 people $(662 \%)$, while respondents for women were 23 people (33.8\%). This indicates that visitors to the Sudimoro coffee center Malang are dominated by men. $b$. Age is dominated by the age range below 20 years (69.1\%); this age is the average age of respondents who visit the Sudimoro Coffee Center in Malang. 


\subsection{Hypothesis Test Results 1}

The first hypothesis in this study is that there is an influence of cognitive attractiveness on visitor satisfaction. Based on the results of the first multiple linear regression analysis above, it shows a significant effect of Cognitive Attractiveness Image on Visitor Satisfaction at the Sudimoro Coffee Center, Malang City. This can be seen from the coefficient of 0.808 with a significant level of $0.000<0.05$. Then H0 is rejected, which means a powerful influence between the Image of Cognitive Attractiveness on Visitor Satisfaction. And also, because the coefficient is positive, which is 0.808 , it can be said that there is a positive and significant influence between the Image of Cognitive Attractiveness (X1) on Visitor Satisfaction.

\subsection{Results of Hypothesis 2 Testing The}

the second hypothesis in this study is that there is an effect of Unique Attractive Image on Visitor Satisfaction. Based on the first multiple linear regression analysis results above, it shows a significant impact of Unique Attractiveness Image on Visitor Satisfaction at the Sudimoro Coffee Center, Malang City. This can be seen from the coefficient of 0.524 with a significant level of $0.001<0.05$. Then $\mathrm{H} 0$ is rejected, which means there is a substantial influence between Unique Attractiveness Imagery on Visitor Satisfaction. And also, because the coefficient is positive, which is 0.524 , it can be said that there is a positive and significant influence between Unique Attractiveness Image and Visitor Satisfaction.

\subsection{Hypothesis Test Results 3}

The third hypothesis in this study is that there is an influence of affective attractiveness on visitor satisfaction. Based on the results of the first multiple linear regression analysis above, it shows a significant effect of Affective Attractiveness Image on Visitor Satisfaction at the Sudimoro Coffee Center, Malang City. This can be seen from the coefficient of - 0.378 with a significant level of $0.000<0.05$. Then $\mathrm{HO}$ is rejected, which means a significant influence between Affective Attractiveness Image on Visitor Satisfaction. However, because the coefficient is negative, which is -0.378 , it can be said that there is a negative and significant influence between Affective Attractiveness Image and Visitor Satisfaction.

\subsection{Results of Hypothesis Testing 4}

The fourth hypothesis in this study is that there is an influence of cognitive attractiveness on visitor loyalty. Based on the second multiple linear regression analysis results above, it shows a significant impact on the Image of Cognitive Attractiveness on the Loyalty of Visitors to the Sudimoro Coffee Center, Malang City. This can be seen from the coefficient of 0.800 with a significant level of $0.000<0.05$. Then H0 is rejected, which means a powerful influence between the Image of Cognitive Attractiveness on Visitor Loyalty. And also, because the coefficient is positive, which is 0.808 , it can be said that there is a positive and significant influence between the Image of Cognitive Attractiveness and Visitor Loyalty.

\subsection{Hypothesis Test Results 5}

The fifth hypothesis in this study is that there is an influence of unique attractiveness image on visitor loyalty. Based on the results of the second multiple linear regression analysis above, it shows a significant effect of Unique Attractiveness Image on the Loyalty of Visitors to the Sudimoro Coffee Center, Malang City. This can be seen from the coefficient of -0.569 with a significant level of $0.000<0.05$. Then $\mathrm{H} 0$ is rejected, which means there is a significant influence between Unique Attractiveness Image and Visitor Loyalty. However, because the coefficient is negative, which is -0.569 , it can be said that there is a negative and significant influence between Unique Attractiveness Image and Visitor Loyalty.

\subsection{Hypothesis Test Results 6}

The sixth hypothesis in this study is that there is an influence of the image of affective attractiveness on visitor loyalty. Based on the second multiple linear regression analysis results above, it shows a significant effect of Affective Attractiveness Image on Visitor Loyalty of Sudimoro Coffee Center Malang City. This can be seen from the coefficient of 0.357 with a significant level of $0.000<0.05$. Then $\mathrm{H} 0$ is rejected, which means a significant influence between Affective Attractiveness Image and Visitor Loyalty. And also, because the coefficient is positive, which is 0.357 , it can be said that there is a positive and significant influence between Affective Attractiveness Image and Visitor Loyalty. 


\subsection{Results of Hypothesis Testing 7}

The seventh hypothesis in this study is that there is visitor satisfaction on visitor loyalty. Based on the results of the second multiple linear regression analysis above, it shows a significant influence on visitor satisfaction on visitor loyalty at the Sudimoro coffee center, Malang City. This can be seen from the coefficient of 0.195 with a significant level of $0.032<0.05$, then H0 is rejected, which means that there is a significant influence between Visitor Satisfaction and Visitor Loyalty. And also, because the coefficient is positive, which is 0.195 , it can be said that there is a positive and significant influence between Visitor Satisfaction and Visitor Loyalty.

\subsection{Hypothesis Test Results 8}

The eighth hypothesis in this study is that there is an influence of cognitive attractiveness on visitor loyalty through visitor satisfaction. Based on the results of the path analysis above, it shows that there is no significant effect of Cognitive Attractiveness Image on Visitor Loyalty through Visitor Satisfaction at the Sudimoro Coffee Center, Malang. This can be seen from the influence of the Image of Cognitive Attractiveness to Visitor Loyalty of 0.800. Meanwhile, the power of the image of cognitive attractiveness on visitor loyalty through visitor satisfaction is 0.158 . This shows a greater direct effect on the indirect effect, so it is said that the Image of Cognitive Attractiveness is having no significant impact on Visitor Loyalty through Visitor Satisfaction.

\subsection{Results of Hypothesis Testing 9 The ninth}

hypothesis in this study is that there is an influence of unique attractiveness images on visitor loyalty through visitor satisfaction. Based on the results of the path analysis above, it shows a significant effect of Unique Attractiveness Image on Visitor Loyalty through Visitor Satisfaction at the Sudimoro Coffee Center, Malang. This can be seen from the impact of Unique Attractiveness Image on Visitor Loyalty of -0.569 . While the effects of Unique Attractiveness Image on Visitor Loyalty through Visitor Satisfaction is 0.102. This shows that the direct result is less than the indirect effect, so it is said that the Unique Attractive Image is having a significant impact on Visitor Loyalty through Visitor Satisfaction.

\subsection{Results of Hypothesis Testing 10}

The tenth hypothesis in this study is that there is an influence of affective attractiveness on visitor loyalty through visitor satisfaction. Based on the results of the path analysis above, it shows that there is no significant effect of Affective Attractiveness Image on Visitor Loyalty through Visitor Satisfaction at the Sudimoro Coffee Center, Malang. This can be seen from the impact of Affective Attractiveness Image on Visitor Loyalty of 0.357. At the same time, the indirect effect of Affective Attractiveness Image on Visitor Loyalty through Visitor Satisfaction is -0.074. This shows that the direct influence is greater on the indirect effect, so it is said that the Image of Affective Attractiveness is having no significant impact on Visitor Loyalty through Visitor Satisfaction.

\section{CONCLUSIONS AND SUGGESTIONS}

\subsection{Conclusion}

a) The results of the descriptive analysis that have been carried out show that the number of respondents based on gender shows that male respondents are 45 people $(662 \%)$, while respondents for women are 23 people (33.8\%). This shows that men dominate visitors to the Sudimoro coffee center Malang. Meanwhile, based on age, it is dominated by the age range below 20 years $(69.1 \%)$, that age is the average age of respondents who visit the Sudimoro coffee center (Malang

b) . Based on the results of the first multiple linear regression analysis above, it shows that there is a significant influence on the Image of Cognitive Attractiveness on the Satisfaction of Visitors to the Sudimoro Coffee Center, Malang City. Sudimoro Malang coffee center, they invited their friends to visit Sudimoro Malang coffee center. And before new customers visit the Sudimoro coffee center Malang, they already know a lot of information about the Sudimoro coffee center. They are confident to visit the Sudimoro coffee center Malang. Besides that, the prices are relatively low compared to the cafes located in the Jl. Soekarno-Hatta, the Sudimoro coffee center, is the customer's choice.

c) The effect of unique attraction image on visitor satisfaction based on the results of the first multiple linear regression analysis above shows a significant influence on amazing attraction image on visitor satisfaction at the Sudimoro coffee center, Malang City. This means that the Sudimoro coffee center is unique compared to other coffee shops in Malang, including the Sudimoro coffee center has many choices of coffee shops so that visitors are free to choose which coffee shop they want to drink, besides 
that, besides the Sudimoro coffee center, Malang serves a choice of coffee there also serves food, which can even vary from light fare to heavy food. Moreover, besides Indonesian food, there are also foods from abroad, such as Japanese and Chinese food adapted to the Sudimoro coffee center; this satisfies visitors to visit the Sudimoro coffee center, Malang City.

d) Effect of Affective Attractiveness Image on Visitor Satisfaction. Based on the results of the first multiple linear regression analysis above, it shows a significant effect of Affective Attractiveness Image on Visitor Satisfaction at the Sudimoro Coffee Center, Malang City. It means that the Sudimoro coffee center is unique compared to other coffee shops in Malang, including the Sudimoro coffee center, which has many, most of the respondents know or know as a coffee connoisseur center. This knowledge encourages tourists to visit the Sudimoro Coffee center with certain reasons/motivations related to get-togethers with relatives, friends, or family. The reason most respondents chose was to refresh their minds and have fun.

e) The Effect of Cognitive Attractiveness Image on Visitor Loyalty. Based on the results of the second multiple linear regression analysis above, it shows a significant influence on the Image of Cognitive Attractiveness on the Loyalty of Visitors to the Sudimoro Coffee Center, Malang City. This means that the existing visitors choose to visit the Sudimoro coffee center for several reasons, including the price and excellent service; besides that, there is a safe parking area and a strategic location because it is close to the center of the crowd and close to campuses such as Brawijaya University, Widyagama University. Unfortunately and so on. Things like that make customers satisfied and loyal. They will influence and invite their friends to visit again and even encourage their acquaintances to visit the Sudimoro coffee center.

f) The Influence of Unique Attraction Image on Visitor Loyalty. Based on the results of the second multiple linear regression analysis above, it shows a significant effect of Unique Attractiveness Image on the Loyalty of Visitors to the Sudimoro Coffee Center, Malang City. This means that existing visitors choose to visit the Sudimoro coffee center again, recommend it to others, or return to the Sudimoro coffee center destination again.

g) Effect of Affective Attractiveness Image on Visitor Loyalty. Based on the results of the second multiple linear regression analysis above, it shows a significant influence of Affective Attractiveness Image on Visitor Loyalty of Sudimoro Coffee Center Malang City. This can be interpreted as a pleasant feeling from their visitors to be very loyal to the Sudimoro Malang coffee center. This can be seen when they come and then gather with their friends who are very old, even up to 4 hours sitting, with a feeling of awakening, relaxing and interesting when at the Sudimoro coffee center, Malang City they spend the night inviting their friends or acquaintances to visit Sudimoro coffee center Malang.

h) Visitor Satisfaction with Visitor Loyalty. Based on the results of the second multiple linear regression analysis above, it shows a significant influence on visitor satisfaction on visitor loyalty at the Sudimoro coffee center, Malang City. This means that visitor loyalty is closely related to visitor satisfaction. The more satisfied visitors are with their desires, or satisfied between expectations and reality, will cause visitors to return to the Sudimoro coffee center and become loyal consumers to the Sudimoro coffee center Malang. Meanwhile, visitor satisfaction is influenced by the services provided at the Sudimoro coffee center, the reputation of the seller or producer, and the quality of the product by visitors' expectations.

i) The Effect of Cognitive Attractiveness Image on Visitor Loyalty through Visitor Satisfaction. Based on the results of the path analysis above, it shows that there is no significant effect of Cognitive Attractiveness Image on Visitor Loyalty through Visitor Satisfaction at the Sudimoro Coffee Center, Malang. This can be seen from the influence of the Image of Cognitive Attractiveness to Visitor Loyalty of 0.800 . Meanwhile, the power of the image of cognitive attractiveness on visitor loyalty through visitor satisfaction is 0.158 . This means that some visitors change coffee places because they want to have a new atmosphere and new friends, so they are reluctant to return to the Sudimoro coffee center in Malang; this is what affects this research so that the Effect of Attractive Cognitive Image is not significant on Visitor Loyalty through Visitor Satisfaction.

j) The Effect of Unique Attractiveness Image on Visitor Loyalty through Visitor Satisfaction. Based on the results of the path analysis above, it shows a significant effect of Unique Attractiveness Image on Visitor Loyalty through Visitor Satisfaction at the Sudimoro Coffee Center, Malang. This means that the uniqueness of the Sudimoro Malang coffee center makes visitors feel satisfied and ultimately makes them loyal. Hence, the impact causes the Sudimoro Malang coffee center to more crowded. It can be seen from 2016 until before the Covid-19 pandemic, the number of visitors increased, especially on weekends, namely Saturday nights and peak weekends, because of the high number of visitors, causing traffic jams around the Sudimoro coffee center in Malang.

k) Effect of Affective Attractiveness Image on Visitor Loyalty through Visitor Satisfaction. Based on the results of the path analysis above, it shows that there is no significant effect of Affective Attractiveness Image on Visitor Loyalty through Visitor Satisfaction at the Sudimoro Coffee Center, Malang. This can often get together with friends and acquaintances to make 
customers lazy to come back to the Sudimoro Malang coffee center. In addition, frequent visits to coffee shops make finances thin, considering that many visitors who come to the Sudimoro Malang coffee center are students who are still not working and relying on remittances from their parents, so by saving money, they put the brakes on spending a little so that loyalty in terms of The image of affective attractiveness through customer satisfaction is not significant.

\subsection{SUGGESTIONS}

Based on the results of the study and the limitations of the study, the suggestions that can be given are as follows:

1. For the government of Malang City \& especially Mojolangu Village, it can increase Sudimoro Coffee culinary tourism as a coffee center in Malang City.

\section{For Knowledge Developers}

Based on the study results, the influence of cognitive, unique, and effective attractiveness images can be seen in the coffee center sector of Sudimoro Malang City.

For Further Researchers

If further researchers are interested in similar topics, they should expand other variables and increase the number of samples. After that, to strengthen research data, it can also be added by conducting interviews with research samples so that the information obtained is not limited to questionnaires in the form of closed questions.

\section{REFERENCES}

[1]. Artuğer, S., et al. 2013. The effect of destination image on destination loyalty: application in Alanya. European Journal of Business and Management, 5 (13): 124-136

[2]. Chiu, W., et al. (2016). "The influence of Citra Wisata and tourist satisfaction on tourist loyalty: a case study of Chinese tourists in Korea." International Journal of Korea

[3]. Coban, Susan. 2012, The effects of the image of destination on tourist satisfaction and loyalty, the case of copadia.

[4]. Hanif, Asya., Kusumawati, Andriani., Mawardi, M.Kholid. 2016. The Effect of Destination Image on Tourist Satisfaction and Its Impact on 56 Tourist Loyalty (Study on Archipelago Tourists who Visit Batu City). Journal of Business Administration (JAB). Vol.38 No.1 September 2016.

[5]. Kotler, and Keller. (2012). Marketing Management. Edition 12. Jakarta Erlangga.

[6]. Kotler, Philip, and Kevin Lane Keller, (2016): Marketing Management, 15th Edition New Jersey: Pearson Pretice Hall, Inc.

[7]. Lovelock, Christopher., Jochen, Wirtz., \& Jacky, Mussry. (2010). Service Marketing - Indonesian Perspective Volume 1. Jakarta: Erlangga Publisher.

[8]. Lovelock, Christopher., Jochen, Wirtz., \& Jacky, Mussry. (2010). Service Marketing - Indonesian Perspective Volume 2. Jakarta: Erlangga Publisher.

[9]. Niemah, KF (2014). Perceptions of foreign tourists on the facilities and services at the Prambanan temple, 6(1), 39-45.

[10]. Sangadji, EM, and Sopiah. 2013. Consumer Behavior: Accompanied Practical Approach: The Association of Research Journals. Yogyakarta: Publisher Andi.

[11]. Setyaningsih, S., \& Murwatiningsih. (2016). The Influence of Motivation, Promotion, and Destination Image on Visitor Satisfaction through Visitor Decisions. Management Analysis Journal, 4(1), 1-17.

[12]. Suprapti. W. (2010). Consumer Behavior Basic Understanding And Its Application In Marketing Strategy. Bali : Udayana University Press.

[13]. Tjiptono, Fandy. 2014, Service Marketing - Principles, Application, and Research, Andi Offset, Yogyakarta. 